\title{
A review on water quality and dairy cattle health: a special emphasis on high-altitude region
}

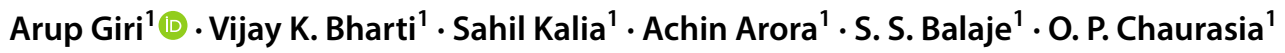

Received: 11 October 2018 / Accepted: 12 February 2020 / Published online: 27 February 2020

(c) The Author(s) 2020

\begin{abstract}
Water is the wonder of nature which is an essential source of nutrient for all forms of life. It helps in proper digestion, energy metabolism, transport of nutrients and metabolites, cellular functions, and excretion of waste materials from our body and animals. Furthermore, water plays a vital role in body thermoregulatory and electrolyte health, and performance the fluidity and cushioning environment for the developing fetus in the human and animals. The quality of water determines the health and productivity of milk and their quality, as it causes bioaccumulation of water solutes in the milk and body tissues. Therefore, its quality has to be good for optimum health, and performance of dairy cattle. The high-altitude environments have limited surface and groundwater resources and more dependent on snow precipitations, very deep bore well groundwater, and mountain river. Recently, quality of high-altitude water resources has become questionable due to more environmental pollution, climate change, and high anthropogenic activities at high altitude. Therefore, there is a continuous requirement to monitor water quality, dairy product quality, and cattle health for prevention and control of waterborne diseases. This review reveals the water quality and the probable effects on the health performance of dairy cattle with a particular emphasis on high-altitude regions. From this review, it can be concluded that global warming and an increase in tourists at high-altitude regions have caused deterioration of water quality, which may affect the health, reproduction, and production of quality dairy products. This may lead to bioaccumulation of some toxic molecules and metals into higher food chain and affecting public health.
\end{abstract}

Keywords Dairy cattle health $\cdot$ Heavy metals $\cdot$ High altitude $\cdot$ Water quality

\section{Introduction}

For the survival of all living organisms, water is crucial. The health of the natural ecosystem depends on the physicochemical and biological characteristics of water (Venkatesharaju et al. 2010). The primary sources of water whether it is plain or high-altitude/mountain regions are groundwater and surface water (rivers, streams, and ponds) for all our social and economical consumption. The worldwide quality of water differs from one location to another location depending upon the environmental factors and locations. There are a number of physical, chemical, and microbiological parameters which are interrelated to define the water quality (Barik and Thorat 2015). Therefore, all of these paramters need to be assessed

Vijay K. Bharti

vijaykbharti@rediffmail.com

1 DRDO-Defence Institute of High Altitude Research (DIHAR), Leh-Ladakh, India critically for better health of dairy cattle and production of quality milk and milk products. The quantification of chemical properties may quantify higher levels of the chemical load in the environment, and at the same instant is applicable for both physical and microbial parameter analysis which will help in assessing the water quality of a region in view of the rapid changes in water quality (Liu and Kujawinski 2015).

Groundwater quality is going to alter due to the increase in population size, industrial effluents, and several types of anthropogenic activity (Barnes et al. 2009). Most concerns of the deteriorating water quality revealed with the high load of heavy metals like arsenic, lead, cadmium, and presence of persistent organic pollutants. Arsenic is ubiquitously present in nature. In India, the number of arsenic-prone zones is increasing due to the overexploitation of groundwater and mainly anthropogenic activity. Arsenicosis also affects livestock animals, and through the food chain, the arsenic level rises in the human population also (Tikenbala et al. 2010). 
Table 1 Review of different physicochemical and microbiological parameters in groundwater

\begin{tabular}{|c|c|c|c|}
\hline S1. no. & Parameters & Reported levels & References \\
\hline \multirow[t]{2}{*}{1.} & \multirow[t]{2}{*}{ Temperature } & $15.51-17.24{ }^{\circ} \mathrm{C}$ & Giri (2018) \\
\hline & & $29.40^{\circ} \mathrm{C}$ & Affum et al. (2015) \\
\hline \multirow[t]{3}{*}{2.} & \multirow[t]{3}{*}{$\mathrm{pH}$} & $7.70-7.97$ & Giri (2018) \\
\hline & & 6.00 & Bariki et al. (2015) \\
\hline & & 5.94 & Affum et al. (2015) \\
\hline \multirow[t]{2}{*}{3.} & \multirow[t]{2}{*}{ Conductivity } & $\begin{array}{l}432.01-488.74 \\
\mu \mathrm{S} / \mathrm{cm}\end{array}$ & Giri (2018) \\
\hline & & $692.00 \mu \mathrm{S} / \mathrm{cm}$ & Affum et al. (2015) \\
\hline \multirow[t]{2}{*}{4.} & \multirow[t]{2}{*}{$\begin{array}{l}\text { Total dissolved } \\
\text { solids }\end{array}$} & $\begin{array}{l}83.42- \\
238.50 \mathrm{mg} / \mathrm{L}\end{array}$ & Giri (2018) \\
\hline & & $345.00 \mathrm{mg} / \mathrm{L}$ & Affum et al. (2015) \\
\hline 5. & Salinity & $0.04-0.21 \mathrm{mg} / \mathrm{L}$ & Giri (2018) \\
\hline \multirow[t]{2}{*}{6.} & \multirow[t]{2}{*}{ Turbidity } & 8.83-24.74 NTU & Giri (2018) \\
\hline & & $5.00 \mathrm{NTU}$ & Bariki et al. (2015) \\
\hline \multirow[t]{2}{*}{7.} & \multirow[t]{2}{*}{ Dissolved oxygen } & $9.76-10.03 \mathrm{mg} / \mathrm{L}$ & Giri (2018) \\
\hline & & $4.90 \mathrm{mg} / \mathrm{L}$ & Bariki et al. (2015) \\
\hline \multirow[t]{2}{*}{8.} & \multirow[t]{2}{*}{ E. coli } & $\begin{array}{l}1.47-12.90 \mathrm{CFU} / \\
\mathrm{mL}\end{array}$ & Giri (2018) \\
\hline & & $<1 \mathrm{CFU} / 100 \mathrm{~mL}$ & Affum et al. (2015) \\
\hline \multirow[t]{3}{*}{9.} & \multirow[t]{3}{*}{ Chloride } & $20.41-22.74 \mathrm{mg} / \mathrm{L}$ & Giri (2018) \\
\hline & & $12.70 \mathrm{mg} / \mathrm{L}$ & Bariki et al. (2015) \\
\hline & & $132.90 \mathrm{mg} / \mathrm{L}$ & Affum et al. (2015) \\
\hline \multirow[t]{2}{*}{10.} & \multirow[t]{2}{*}{ Alkalinity } & $\begin{array}{l}442.54- \\
\quad 494.49 \mathrm{mg} / \mathrm{L}\end{array}$ & Giri (2018) \\
\hline & & $13.50 \mathrm{mg} / \mathrm{L}$ & Affum et al. (2015) \\
\hline \multirow[t]{2}{*}{11.} & \multirow[t]{2}{*}{ Calcium hardness } & $\begin{array}{l}129.19- \\
134.26 \mathrm{mg} / \mathrm{L}\end{array}$ & Giri (2018) \\
\hline & & $<0.50 \mathrm{mg} / \mathrm{L}$ & Affum et al. (2015) \\
\hline \multirow[t]{3}{*}{12.} & \multirow[t]{3}{*}{ Total hardness } & $\begin{array}{l}184.26- \\
256.50 \mathrm{mg} / \mathrm{L}\end{array}$ & Giri (2018) \\
\hline & & $84.00 \mathrm{mg} / \mathrm{L}$ & Bariki et al. (2015) \\
\hline & & $45.80 \mathrm{mg} / \mathrm{L}$ & Affum et al. (2015) \\
\hline \multirow[t]{3}{*}{13.} & \multirow[t]{3}{*}{ Sulfate } & $2.84-5.59 \mathrm{mg} / \mathrm{L}$ & Giri (2018) \\
\hline & & $0.90 \mathrm{mg} / \mathrm{L}$ & Bariki et al. (2015) \\
\hline & & $82.90 \mathrm{mg} / \mathrm{L}$ & Affum et al. (2015) \\
\hline \multirow[t]{2}{*}{14.} & \multirow[t]{2}{*}{ Phosphate } & $0.03-0.04 \mathrm{mg} / \mathrm{L}$ & Giri (2018) \\
\hline & & $0.09 \mathrm{mg} / \mathrm{L}$ & Affum et al. (2015) \\
\hline 15. & Carbonate & $2.69-3.72 \mathrm{mg} / \mathrm{L}$ & Giri (2018) \\
\hline \multirow[t]{2}{*}{16.} & \multirow[t]{2}{*}{ Bicarbonate } & $27.15-28.25 \mathrm{mg} / \mathrm{L}$ & Giri (2018) \\
\hline & & $13.50 \mathrm{mg} / \mathrm{L}$ & Affum et al. (2015) \\
\hline 17. & Nitrate & $0.15-0.22 \mathrm{mg} / \mathrm{L}$ & Giri (2018) \\
\hline & & $\begin{array}{l}\text { Below detection } \\
\text { limit }\end{array}$ & Bariki et al. (2015) \\
\hline & & $0.60 \mathrm{mg} / \mathrm{L}$ & Affum et al. (2015) \\
\hline 18. & TOC & $1.92-2.94 \mathrm{mg} / \mathrm{L}$ & Giri (2018) \\
\hline
\end{tabular}

Among the heavy metals, lead, arsenic, and cadmium causes the most hazards in domestic animals. Due to mainly anthropogenic activity, the environment is getting contaminated with a higher level of these heavy metals.
Table 2 Review of different trace minerals and metals level in groundwater

\begin{tabular}{|c|c|c|c|}
\hline Sl. no. & Constituents & Reported levels & References \\
\hline \multirow[t]{2}{*}{1.} & \multirow[t]{2}{*}{ Cadmium (Cd) } & $\begin{array}{l}0.0007- \\
0.0019 \mathrm{mg} / \mathrm{L}\end{array}$ & Giri (2018) \\
\hline & & $<0.002 \mu \mathrm{g} / \mathrm{L}$ & Affum et al. (2015) \\
\hline 2. & Lead $(\mathrm{Pb})$ & $\begin{array}{l}0.0021- \\
0.0023 \mathrm{mg} / \mathrm{L}\end{array}$ & Giri (2018) \\
\hline \multirow[t]{2}{*}{3.} & \multirow[t]{2}{*}{ Arsenic (As) } & $\begin{array}{l}0.0265- \\
0.0300 \mathrm{mg} / \mathrm{L}\end{array}$ & Giri (2018) \\
\hline & & $44.00 \mu \mathrm{g} / \mathrm{L}$ & Affum et al. (2015) \\
\hline \multirow[t]{2}{*}{4.} & \multirow[t]{2}{*}{ Copper $(\mathrm{Cu})$} & $1.06 \mathrm{mg} / \mathrm{L}$ & Giri (2018) \\
\hline & & $4.90 \mathrm{mg} / \mathrm{L}$ & Huang et al. (2013) \\
\hline \multirow[t]{2}{*}{5.} & \multirow[t]{2}{*}{ Zinc $(\mathrm{Zn})$} & $2.87-3.12 \mathrm{mg} / \mathrm{L}$ & Giri (2018) \\
\hline & & $0.11 \mathrm{mg} / \mathrm{L}$ & Solange et al. (2013) \\
\hline \multirow[t]{3}{*}{6.} & \multirow[t]{3}{*}{ Calcium (Ca) } & $87.40-93.43 \mathrm{mg} / \mathrm{L}$ & Giri (2018) \\
\hline & & $44.00 \mathrm{mg} / \mathrm{L}$ & Bariki et al. (2015) \\
\hline & & $<0.01 \mathrm{mg} / \mathrm{L}$ & Affum et al. (2015) \\
\hline \multirow[t]{3}{*}{7.} & \multirow[t]{3}{*}{ Magnesium (Mg) } & $33.41-33.67 \mathrm{mg} / \mathrm{L}$ & Giri (2018) \\
\hline & & $40.00 \mathrm{mg} / \mathrm{L}$ & Bariki et al. (2015) \\
\hline & & $11.10 \mathrm{mg} / \mathrm{L}$ & Affum et al. (2015) \\
\hline \multirow[t]{2}{*}{8.} & \multirow[t]{2}{*}{ Iron $(\mathrm{Fe})$} & $1.03-1.05 \mathrm{mg} / \mathrm{L}$ & Giri (2018) \\
\hline & & $0.551 \mathrm{mg} / \mathrm{L}$ & Singh et al. (2011) \\
\hline 9. & Cobalt (Co) & $\begin{array}{l}0.0075- \\
0.0089 \mathrm{mg} / \mathrm{L}\end{array}$ & Giri (2018) \\
\hline \multirow[t]{2}{*}{10.} & \multirow[t]{2}{*}{ Manganese (Mn) } & $2.99-3.36 \mathrm{mg} / \mathrm{L}$ & Giri (2018) \\
\hline & & $0.40 \mathrm{mg} / \mathrm{L}$ & Salem et al. (2014) \\
\hline \multirow[t]{2}{*}{11.} & \multirow[t]{2}{*}{ Sodium (Na) } & $61.58-62.92 \mathrm{mg} / \mathrm{L}$ & Giri (2018) \\
\hline & & $265.50 \mathrm{mg} / \mathrm{L}$ & Affum et al. (2015) \\
\hline \multirow[t]{2}{*}{12.} & \multirow[t]{2}{*}{ Potassium (K) } & $30.08-30.12 \mathrm{mg} / \mathrm{L}$ & Giri (2018) \\
\hline & & $5.60 \mathrm{mg} / \mathrm{L}$ & Affum et al. (2015) \\
\hline \multirow[t]{2}{*}{13.} & \multirow[t]{2}{*}{ Boron (B) } & $1.63-1.70 \mathrm{mg} / \mathrm{L}$ & Giri (2018) \\
\hline & & $32.00 \mathrm{mg} / \mathrm{L}$ & Rango et al. 2012 \\
\hline \multirow[t]{2}{*}{14.} & \multirow[t]{2}{*}{ Selenium (Se) } & $0.05-0.06 \mathrm{mg} / \mathrm{L}$ & Giri (2018) \\
\hline & & $1.30 \mu \mathrm{g} / \mathrm{L}$ & Huang et al. (2013) \\
\hline \multirow[t]{2}{*}{15.} & \multirow[t]{2}{*}{ Silicon $(\mathrm{Si})$} & $6.12-6.34 \mathrm{mg} / \mathrm{L}$ & Giri (2018) \\
\hline & & $0.43 \mathrm{mg} / \mathrm{L}$ & Solange et al. (2013) \\
\hline \multirow[t]{2}{*}{16.} & \multirow[t]{2}{*}{ Aluminum (Al) } & $0.86 \mathrm{mg} / \mathrm{L}$ & Giri (2018) \\
\hline & & $0.67 \mu \mathrm{g} / \mathrm{L}$ & Solange et al. (2013) \\
\hline
\end{tabular}

Rapid industrialization increases lead poisoning in urban dairy cattle than the rural cattle. Many studies found that lead poisoning is most common in calves (Cowan and Blakley 2016; Chiwome et al. 2017). Cattle were mainly exposed to the lead after drinking crankcase oil, licking machinery grease, newspapers, and chewing batteries (Cowan and Blakley 2016). It has been found that reticulum is the main site for lead deposition (Cowan and Blakley 2016; Priyanka and Dey 2018).

Currently, in the developing country, numerous health problems are arising due to over access to contaminated water, which becomes a great concern to the government 
Table 3 Review of different physicochemical and microbiological parameters in river water

\begin{tabular}{|c|c|c|c|}
\hline Sl. no. & Parameters & Reported levels & References \\
\hline 1. & Temperature & $\begin{array}{l}14.88-15.66^{\circ} \mathrm{C} \\
33.51^{\circ} \mathrm{C}\end{array}$ & $\begin{array}{l}\text { Giri (2018) } \\
\text { Kumar et al. (2015) }\end{array}$ \\
\hline 2. & $\mathrm{pH}$ & $\begin{array}{l}8.33-8.36 \\
7.07\end{array}$ & $\begin{array}{l}\text { Giri (2018) } \\
\text { Sarma et al. (2017) }\end{array}$ \\
\hline 3. & Conductivity & $\begin{array}{l}325.65-336.43 \mu \mathrm{S} / \mathrm{cm} \\
977.60 \mu \mathrm{S} / \mathrm{cm}\end{array}$ & $\begin{array}{l}\text { Giri (2018) } \\
\text { Kumar et al. (2015) }\end{array}$ \\
\hline 4. & Total dissolved solids & $\begin{array}{l}103.46-155.41 \mathrm{mg} / \mathrm{L} \\
689.90 \mathrm{mg} / \mathrm{L}\end{array}$ & $\begin{array}{l}\text { Giri (2018) } \\
\text { Kumar et al. (2015) }\end{array}$ \\
\hline 5. & Salinity & $\begin{array}{l}0.10-0.11 \mathrm{mg} / \mathrm{L} \\
0.01-0.02 \mathrm{mg} / \mathrm{L} \\
0.12 \mathrm{mg} / \mathrm{L}\end{array}$ & $\begin{array}{l}\text { Giri (2018) } \\
\text { Khalik et al. (2013) } \\
\text { Charan (2013) }\end{array}$ \\
\hline 6. & Turbidity & $\begin{array}{l}3.38-4.97 \mathrm{NTU} \\
9.80 \mathrm{NTU} \\
42.78 \mathrm{NTU}\end{array}$ & $\begin{array}{l}\text { Giri (2018) } \\
\text { Sarma et al. (2017) } \\
\text { Kumar et al. (2015) }\end{array}$ \\
\hline 7. & Dissolved oxygen & $\begin{array}{l}10.17-10.69 \mathrm{mg} / \mathrm{L} \\
7.27 \mathrm{mg} / \mathrm{L}\end{array}$ & $\begin{array}{l}\text { Giri (2018) } \\
\text { Kumar et al. (2015) }\end{array}$ \\
\hline 8. & E. coli & $\begin{array}{l}\text { 6.48-8.18 CFU/mL } \\
236.00 \mathrm{CFU} / \mathrm{mL}\end{array}$ & $\begin{array}{l}\text { Giri (2018) } \\
\text { Kumar et al. (2015) }\end{array}$ \\
\hline 9. & Chloride & $\begin{array}{l}20.44-23.48 \mathrm{mg} / \mathrm{L} \\
9.50 \mathrm{mg} / \mathrm{L} \\
74.55 \mathrm{mg} / \mathrm{L}\end{array}$ & $\begin{array}{l}\text { Giri (2018) } \\
\text { Sarma et al. (2017) } \\
\text { Kumar et al. (2015) }\end{array}$ \\
\hline 10. & Alkalinity & $\begin{array}{l}319.25-333.43 \mathrm{mg} / \mathrm{L} \\
431.50 \mathrm{mg} / \mathrm{L} \\
22.00 \mathrm{mg} / \mathrm{L}\end{array}$ & $\begin{array}{l}\text { Giri (2018) } \\
\text { Kumar et al. (2015) } \\
\text { Eze and Chigbu (2015) }\end{array}$ \\
\hline 11. & Calcium hardness & $\begin{array}{l}53.85-88.33 \mathrm{mg} / \mathrm{L} \\
78.56 \mathrm{mg} / \mathrm{L}\end{array}$ & $\begin{array}{l}\text { Giri (2018) } \\
\text { Kumar et al. (2010) }\end{array}$ \\
\hline 12. & Total hardness & $\begin{array}{l}150.67-187.27 \mathrm{mg} / \mathrm{L} \\
66.50 \mathrm{mg} / \mathrm{L} \\
240.80 \mathrm{mg} / \mathrm{L}\end{array}$ & $\begin{array}{l}\text { Giri (2018) } \\
\text { Sarma et al. (2017) } \\
\text { Kumar et al. (2015) }\end{array}$ \\
\hline 13. & Sulfate & $\begin{array}{l}2.28-3.92 \mathrm{mg} / \mathrm{L} \\
20.59 \mathrm{mg} / \mathrm{L} \\
0.103 \mathrm{mg} / \mathrm{L} \\
73.60 \mathrm{mg} / \mathrm{L}\end{array}$ & $\begin{array}{l}\text { Giri (2018) } \\
\text { Kumar et al. (2015) } \\
\text { Eze and Chigbu (2015) } \\
\text { Sahoo et al. (2016) }\end{array}$ \\
\hline 14. & Phosphate & $\begin{array}{l}0.27-0.35 \mathrm{mg} / \mathrm{L} \\
47.70 \mathrm{mg} / \mathrm{L} \\
0.072 \mathrm{mg} / \mathrm{L}\end{array}$ & $\begin{array}{l}\text { Giri (2018) } \\
\text { Kumar et al. (2015) } \\
\text { Eze and Chigbu (2015) }\end{array}$ \\
\hline 15. & Carbonate & $\begin{array}{l}2.55-2.99 \mathrm{mg} / \mathrm{L} \\
16.02 \mathrm{mg} / \mathrm{L} \\
2.30 \mathrm{mg} / \mathrm{L}\end{array}$ & $\begin{array}{l}\text { Giri (2018) } \\
\text { Eze and Chigbu (2015) } \\
\text { Bourasi et al. (2016) }\end{array}$ \\
\hline 16. & Bicarbonate & $\begin{array}{l}21.26-23.46 \mathrm{mg} / \mathrm{L} \\
26.84 \mathrm{mg} / \mathrm{L} \\
172.62-154.45 \mathrm{mg} / \mathrm{L}\end{array}$ & $\begin{array}{l}\text { Giri (2018) } \\
\text { Eze and Chigbu (2015) } \\
\text { Kumar et al. (2017) }\end{array}$ \\
\hline 17. & Nitrate & $\begin{array}{l}0.04-0.12 \mathrm{mg} / \mathrm{L} \\
3.40 \mathrm{mg} / \mathrm{L} \\
515.30 \mathrm{mg} / \mathrm{L}\end{array}$ & $\begin{array}{l}\text { Giri (2018) } \\
\text { Sarma et al. (2017) } \\
\text { Kumar et al. (2015) }\end{array}$ \\
\hline 18. & TOC & $\begin{array}{l}0.92-1.07 \mathrm{mg} / \mathrm{L} \\
117.85 \mathrm{mg} / \mathrm{L}\end{array}$ & $\begin{array}{l}\text { Giri (2018) } \\
\text { Kumar et al. (2015) }\end{array}$ \\
\hline
\end{tabular}


Table 4 Level of different minerals and heavy metals in river water

\begin{tabular}{|c|c|c|c|}
\hline Sl. no. & Constituents & Reported levels & References \\
\hline 1. & Cadmium (Cd) & $\begin{array}{l}0.0020-0.0041 \mathrm{mg} / \mathrm{L} \\
0.019-0.045 \mathrm{mg} / \mathrm{L}\end{array}$ & $\begin{array}{l}\text { Giri (2018) } \\
\text { Charan (2013) }\end{array}$ \\
\hline 2. & Lead $(\mathrm{Pb})$ & $\begin{array}{l}0.0037-0.0054 \mathrm{mg} / \mathrm{L} \\
0.039-228.00 \mathrm{mg} / \mathrm{L}\end{array}$ & $\begin{array}{l}\text { Giri (2018) } \\
\text { Charan (2013) }\end{array}$ \\
\hline 3. & Arsenic (As) & $\begin{array}{l}0.0268-0.0621 \mathrm{mg} / \mathrm{L} \\
<0.001 \mathrm{mg} / \mathrm{L}\end{array}$ & $\begin{array}{l}\text { Giri (2018) } \\
\text { Eze and Chigbu (2015) }\end{array}$ \\
\hline 4. & Copper $(\mathrm{Cu})$ & $\begin{array}{l}1.03-1.04 \mathrm{mg} / \mathrm{L} \\
0.50 \mathrm{mg} / \mathrm{L}\end{array}$ & $\begin{array}{l}\text { Giri (2018) } \\
\text { Ambedkar and Muniyan (2012) }\end{array}$ \\
\hline 5. & Zinc (Zn) & $\begin{array}{l}0.46-0.48 \mathrm{mg} / \mathrm{L} \\
0.341 \mathrm{mg} / \mathrm{L}\end{array}$ & $\begin{array}{l}\text { Giri (2018) } \\
\text { Charan (2013) }\end{array}$ \\
\hline 6. & Calcium (Ca) & $\begin{array}{l}66.99-70.28 \mathrm{mg} / \mathrm{L} \\
32.00 \mathrm{mg} / \mathrm{L}\end{array}$ & $\begin{array}{l}\text { Giri (2018) } \\
\text { Bourasi et al. (2016) }\end{array}$ \\
\hline 7. & Magnesium (Mg) & $\begin{array}{l}31.18-31.49 \mathrm{mg} / \mathrm{L} \\
19.3 \mathrm{mg} / \mathrm{L} \\
6.45-8.67 \mathrm{mg} / \mathrm{L}\end{array}$ & $\begin{array}{l}\text { Giri (2018) } \\
\text { Bourasi et al. (2016) } \\
\text { Potasznik and Szymczyk (2015) }\end{array}$ \\
\hline 8. & Iron $(\mathrm{Fe})$ & $\begin{array}{l}1.06-1.07 \mathrm{mg} / \mathrm{L} \\
1.10 \mathrm{mg} / \mathrm{L} \\
0.041 \mathrm{mg} / \mathrm{L} \\
0.022 \mathrm{mg} / \mathrm{L} \\
0.11 \mathrm{mg} / \mathrm{L}\end{array}$ & $\begin{array}{l}\text { Giri (2018) } \\
\text { Sarma et al. (2017) } \\
\text { Eze and Chigbu (2015) } \\
\text { Shally et al. (2016) } \\
\text { Bourasi et al. (2016) }\end{array}$ \\
\hline 9. & Cobalt (Co) & $\begin{array}{l}0.0058-0.0063 \mathrm{mg} / \mathrm{L} \\
0.03-0.07 \mathrm{mg} / \mathrm{L} \\
0.0135 \mathrm{mg} / \mathrm{L} \\
0.63 \mathrm{mg} / \mathrm{L}\end{array}$ & $\begin{array}{l}\text { Giri (2018) } \\
\text { Bhuyan and Bakar (2017) } \\
\text { Vaishnavi and Gupta (2015) } \\
\text { Okegye and Gajere (2015) }\end{array}$ \\
\hline 10. & Manganese (Mn) & $\begin{array}{l}0.62-1.23 \mathrm{mg} / \mathrm{L} \\
0.35 \mathrm{mg} / \mathrm{L}\end{array}$ & $\begin{array}{l}\text { Giri (2018) } \\
\text { Sarma et al. (2017) }\end{array}$ \\
\hline 11. & Sodium (Na) & $\begin{array}{l}60.98-62.16 \mathrm{mg} / \mathrm{L} \\
1.41 \mathrm{mg} / \mathrm{L} \\
48-51 \mathrm{mg} / \mathrm{L}\end{array}$ & $\begin{array}{l}\text { Giri (2018) } \\
\text { Sahoo et al. (2016) } \\
\text { Sasikala et al. (2015) }\end{array}$ \\
\hline 12. & Potassium (K) & $\begin{array}{l}30.60-31.63 \mathrm{mg} / \mathrm{L} \\
2.16 \mathrm{mg} / \mathrm{L} \\
3.00-5.00 \mathrm{mg} / \mathrm{L}\end{array}$ & $\begin{array}{l}\text { Giri (2018) } \\
\text { Sahoo et al. (2016) } \\
\text { Sasikala et al. (2015) }\end{array}$ \\
\hline 13. & Boron (B) & $\begin{array}{l}2.07-2.10 \mathrm{mg} / \mathrm{L} \\
1.47 \mathrm{mg} / \mathrm{L}\end{array}$ & $\begin{array}{l}\text { Giri (2018) } \\
\text { Charan (2013) }\end{array}$ \\
\hline 14. & Silicon $(\mathrm{Si})$ & $\begin{array}{l}5.53-9.28 \mathrm{mg} / \mathrm{L} \\
0.52-0.61 \mathrm{mg} / \mathrm{L}\end{array}$ & $\begin{array}{l}\text { Giri (2018) } \\
\text { Patra et al. (2011) }\end{array}$ \\
\hline 15. & Aluminum (Al) & $\begin{array}{l}0.85-0.86 \mathrm{mg} / \mathrm{L} \\
4.20-11.90 \mathrm{mg} / \mathrm{L}\end{array}$ & $\begin{array}{l}\text { Giri (2018) } \\
\text { Bhuyan and Bakar (2017) }\end{array}$ \\
\hline
\end{tabular}

in these countries (Barik and Thorat 2015). These countries regularly have one billion or more incidents of diarrhea annually (Mark et al. 2002). It is estimated that one-third of the world population is using groundwater for drinking (WHO 2002). On the contrary, about eighty percent of natural water is wastewater type, which is not suitable for drinking, agriculture, and industry use. In the global scenario, approximately 1.1 billion people cannot use the improved source of water supply. Moreover, two million deaths per annum occur due to diarrhea. These cases are happening because of the unsafe drinking water supply and improper sanitation (WHO 2013). According to the different 
Table 5 Details of various high-altitude regions in different countries (adopted from

Mountains of the World 2002)

\begin{tabular}{|c|c|c|c|}
\hline Sl. no. & Country/regions name & Highest point name & Elevation $(\mathrm{m})$ \\
\hline 1. & Afghanistan & Noshaq & 7492 \\
\hline 2. & Albania & Korab & 2764 \\
\hline 3. & Algeria & Mount Tahat & 3003 \\
\hline 4. & Andorra & Coma Pedrosa & 2942 \\
\hline 5. & Antarctica & Mount Vinson & 4892 \\
\hline 6. & Argentina & Aconcagua & 6960 \\
\hline 7. & Armenia & Mount Aragats & 4090 \\
\hline 8. & Austria & Grossglockner & 3798 \\
\hline 9. & Azerbaijan & Mount Bazardüzü & 4485 \\
\hline 10. & Bhutan & Gangkhar Puensum & 7570 \\
\hline 11. & Bolivia & Sajama & 6542 \\
\hline 12. & Brazil & Pico da Neblina & 2995 \\
\hline 13. & Bulgaria & Musala & 2925 \\
\hline 14. & Burundi & Mount Heha & 2684 \\
\hline 15 . & Cameroon & Mount Cameroon & 4040 \\
\hline 16. & Canada & Mount Logan & 5959 \\
\hline 17. & Cape Verde & Pico do Fogo & 2829 \\
\hline 18. & Chad & Emi Koussi & 3445 \\
\hline 19. & Chile & Ojos del Salado & 6893 \\
\hline 20. & China & Mount Everest & 8848 \\
\hline 21. & Colombia & Pico Cristóbal Colón Pico Simón Bolívar & 5700 \\
\hline 22. & $\begin{array}{l}\text { Democratic Republic of the } \\
\text { Congo }\end{array}$ & Margherita Peak & 5109 \\
\hline 23. & Costa Rica & Cerro Chirripó & 3820 \\
\hline 24. & Dominican Republic & Pico Duarte & 3098 \\
\hline 25 . & Ecuador & Chimborazo & 6267 \\
\hline 26. & Egypt & Mount Catherine & 2629 \\
\hline 27. & Equatorial Guinea & Pico Basile on Bioko & 3008 \\
\hline 28. & Eritrea & Emba Soira & 3018 \\
\hline 29. & Ethiopia & Ras Dejen & 4550 \\
\hline 30. & France & Mont Blanc & 4810 \\
\hline 31. & Georgia & Shkhara & 5201 \\
\hline 32. & Germany & Zugspitze & 2962 \\
\hline 33. & Greece & Mount Olympus & 2919 \\
\hline 34. & Greenland & Gunnbjørn Fjeld on Greenland & 3700 \\
\hline 35. & Guatemala & Volcán Tajumulco & 4220 \\
\hline 36. & Guyana & Mount Roraima & 2750 \\
\hline 37. & India & Kangchenjunga & 8586 \\
\hline 38. & Indonesia & Puncak Jaya & 4884 \\
\hline 39. & Iran & Damavand & 5610 \\
\hline 40. & Iraq & Cheekha Dar & 3611 \\
\hline 41. & Italy & Monte Bianco & 4810 \\
\hline 42. & Japan & Mount Fuji on Honshu & 3776 \\
\hline 43. & Kazakhstan & Khan Tengri & 7010 \\
\hline 44. & Kenya & Mount Kenya & 5199 \\
\hline 45. & Kyrgyzstan & Jengish Chokusu & 7439 \\
\hline 46. & Lebanon & Qurnat as Sawda & 3088 \\
\hline 47. & Lesotho & Thabana Ntlenyana & 3482 \\
\hline 48. & Malawi & Mount Mulanje & 3002 \\
\hline 49. & Malaysia & Gunung Kinabalu on Borneo & 4095 \\
\hline 50. & Mexico & Volcán Citlaltépetl (Pico de Orizaba) & 5636 \\
\hline
\end{tabular}


Table 5 (continued)

\begin{tabular}{|c|c|c|c|}
\hline Sl. no. & Country/regions name & Highest point name & Elevation $(\mathrm{m})$ \\
\hline 51. & Mongolia & Khüiten Peak & 4374 \\
\hline 52. & Morocco & Jbel Toubkal & 4165 \\
\hline 53. & Myanmar & Hkakabo Razi & 5881 \\
\hline 54. & Nepal & Mount Everest & 8848 \\
\hline 55. & New Zealand & Aoraki/Mount Cook in the South Island & 3724 \\
\hline 56. & Oman & Jabal Shams & 3009 \\
\hline 57. & Pakistan & $\mathrm{K}_{2}$ & 8611 \\
\hline 58. & Panama & Volcán Barú & 3475 \\
\hline 59. & Papua New Guinea & Mount Wilhelm & 4509 \\
\hline 60. & Peru & Huascarán & 6768 \\
\hline 61. & Philippines & Mount Apo on Mindanao & 2954 \\
\hline 62. & Réunion & Piton des Neiges & 3069 \\
\hline 63. & Russia & Mount Elbrus & 5642 \\
\hline 64. & Rwanda & Mount Karisimbi & 4507 \\
\hline 65. & Saudi Arabia & Jabal Sawda & 3000 \\
\hline 66. & South Africa & Mafadi & 3450 \\
\hline 67. & South Sudan & Kinyeti & 3187 \\
\hline 68. & Spain & Teide on Tenerife & 3718 \\
\hline 69. & Sudan & Deriba Caldera & 3042 \\
\hline 70. & Switzerland & Dufourspitze (Monte Rosa) & 4634 \\
\hline 71. & Taiwan & Yu Shan & 3952 \\
\hline 72. & Tajikistan & Ismoil Somoni Peak & 7495 \\
\hline 73. & Tanzania & Kilimanjaro & 5892 \\
\hline 74. & Turkey & Mount Ararat & 5137 \\
\hline 75. & Turkmenistan & Aýrybaba & 3139 \\
\hline 76. & Uganda & Margherita Peak & 5109 \\
\hline 77. & United States & Denali & 6190.5 \\
\hline 78. & Uzbekistan & Khazret Sultan & 4643 \\
\hline 79. & Venezuela & Pico Bolívar & 4978 \\
\hline 80. & Vietnam & Fan Si Pan & 3143 \\
\hline 81. & Yemen & Jabal an Nabi Shu'ayb & 3666 \\
\hline
\end{tabular}

international agencies like WHO, CPCB, BIS, and ICMR, in India, seventy percent of river water quality has contaminated due to an increasing level of direct pollutant discharges in rivers. Some of the river water in India is highly contaminated that cannot be used for any purpose (Daud et al. 2017; Rodriguez-Tapia and Morales-Novelo 2017). In India, about $95 \%$ of the rural population depends on groundwater for their primary domestic uses. Around $70 \%$ of the total water resources are severely polluted. Further, $75 \%$ of illness and $80 \%$ of child mortality are attributed to water pollution as groundwater has been deteriorated in the plain area as well as in high-altitude regions (Aris et al. 2009; Giri 2018).

The high temperature is causing the melting of glaciers, altered pattern of precipitation, and snowfall. The water level in groundwater is decreasing and quality deteriorating due to the irregular pattern of rainfall and high population loading. Socioeconomic balance is now under a tremendous pressure due to the scarcity of water in terms of quality and quantity.
As there is an increase in dynamic flow of population at highaltitude region, water quality is also deteriorating from the last decade in most of the high-altitude regions throughout the globe (Giri 2018; Giri et al. 2017; Bharti et al. 2017a).

In this scenario of deteriorating water quality of different sources in the world, the present study has taken into account to review the various causes deterioratting the water quality and their effects on animal health with particular emphasis on the water quality at high-altitude regions.

\section{Water quality evaluations of different sources at low-altitude region}

\section{Groundwater resource}

Alves (2002) examined the drinking water for the microbiological quality after the collection of 18 samples from 


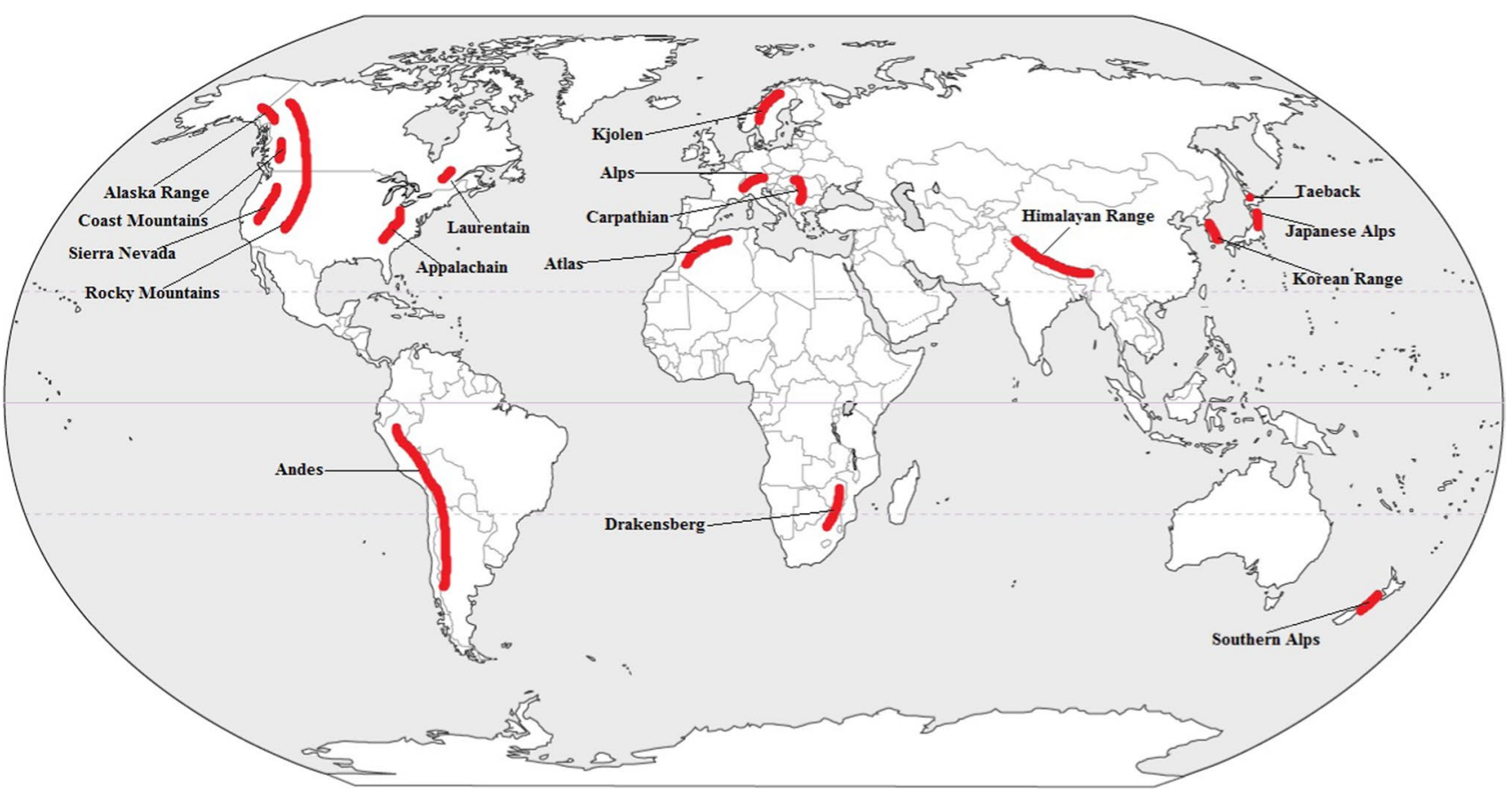

Fig. 1 Location of different high-altitude regions around the globe. Adopted from nationsonline.org

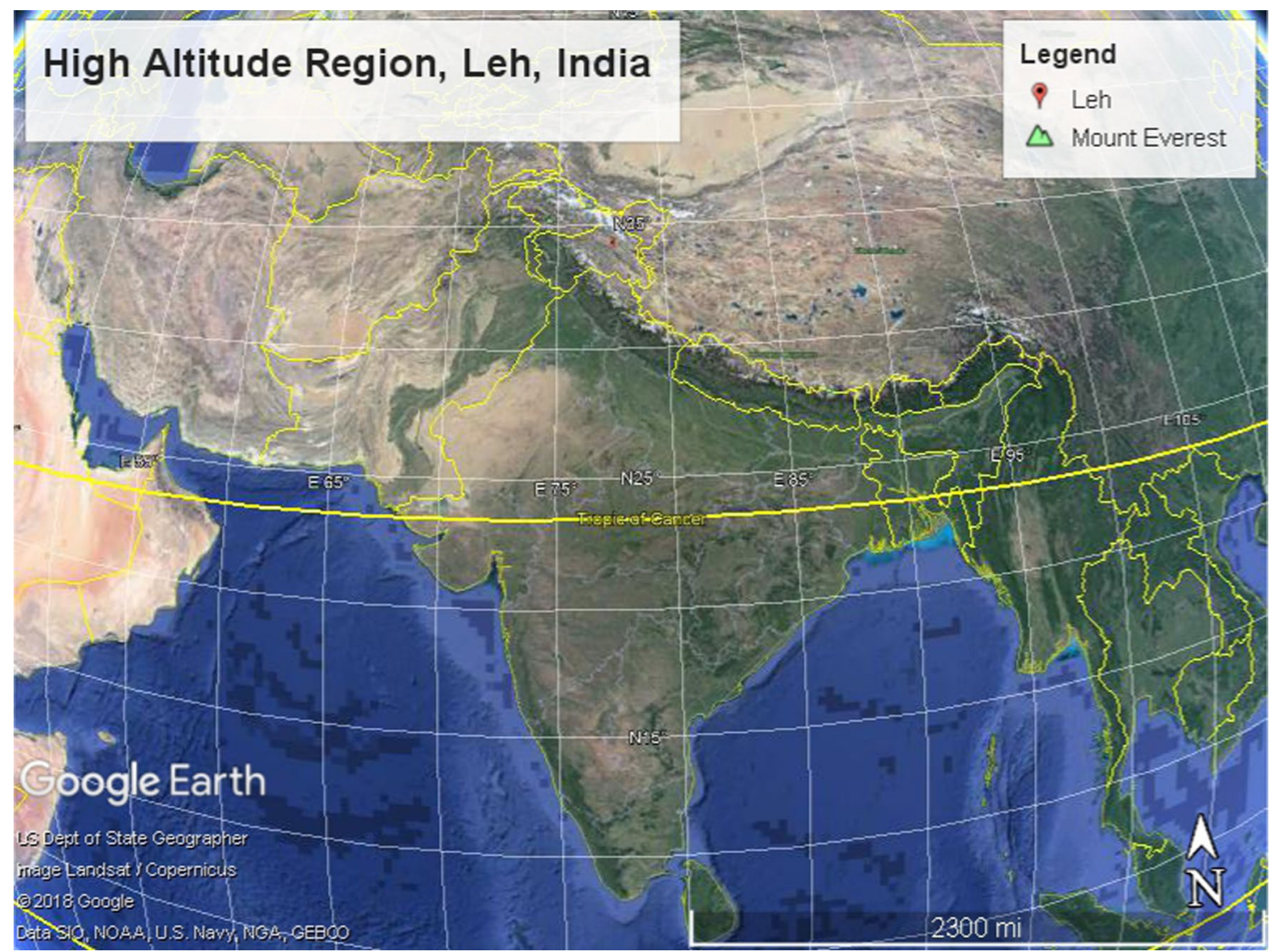

Fig. 2 Experimental location in Leh, a high-altitude region of India. Map prepared using Google Earth 3D Pro Software 


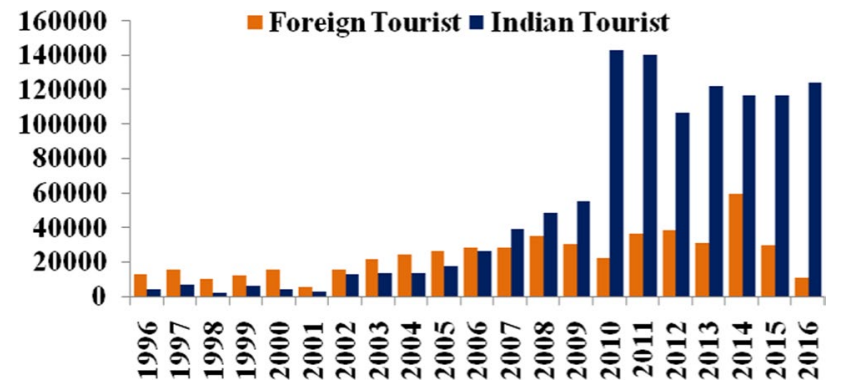

Fig. 3 Tourist load in Leh, Ladakh, India from 1996 to 2016. Source Ladakh Tourism Center, Leh, India

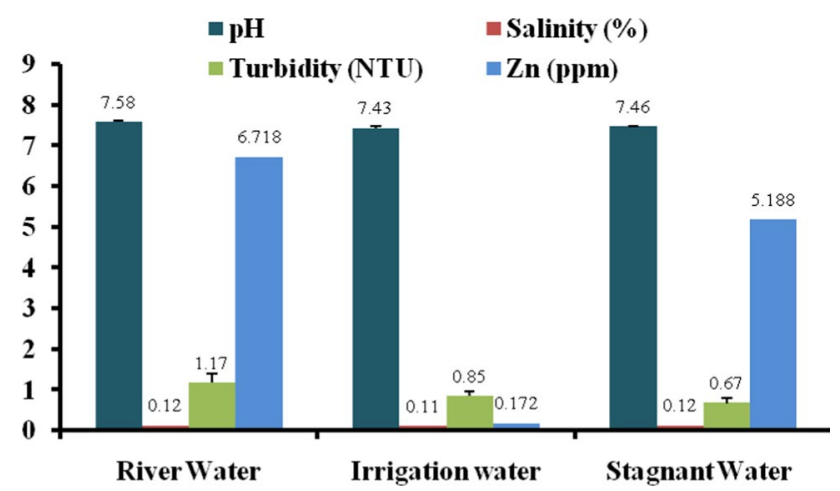

Fig. 4 Level of $\mathrm{pH}$, turbidity, salinity, and $\mathrm{Zn}$ level in different sources of water from high-altitude region of India

some areas of Brazil. Results showed that reservoir water was contaminated with coliform group bacteria.

Shittu et al. (2008) analyzed well water for the physicochemical analyses in Nigeria. The results were compared with the prescribed limit of the EPA and WHO. They interpreted that most of the physicochemical parameters were within the normal level of the WHO and EPA.

Ukpong et al. (2012) analyzed groundwater samples for physicochemical and bacterial parameters. Results showed

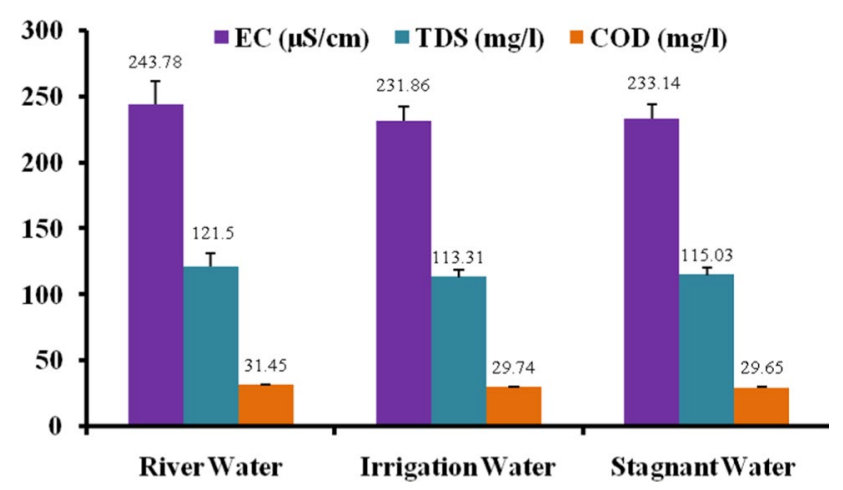

Fig. 5 Level of EC, TDS, and COD level in different sources of water from high-altitude region of India that except for coliform bacteria, water might be consumable for drinking purposes. The range of total coliform count was from 0 to $38 \mathrm{CFU} / 100 \mathrm{ml}$.

Narasimha et al. (2012) studied the drinking water for the physicochemical parameters. The result showed that about $27.7 \%$ of groundwater samples have higher level of chloride than the prescribed limit of WHO guidelines. An extensive review has been done on the physicochemical, microbiological, and minerals level in groundwater, as presented in Tables 1 and 2.

\section{River water resource}

Debels et al. (2005) studied on the Chilean River in Central Chile. They observed that in the dry season, water quality conditions were critical mainly due to the direct discharge of wastewater from the urban area to the river.

A study conducted on the Pamba River water quality in Kerala (John 2009), and samples were analyzed for different physicochemical parameters like salinity, turbidity, temperature, dissolved oxygen, $\mathrm{pH}$, dissolved carbon dioxide, etc. The study found that river water has a high salinity level than the prescribed limit by WHO.

Khalik et al. (2013) conducted a study on the physicochemical parameters of Bertam River located in Cameron Highlands. The result indicates that the Bertam River water quality was deteriorating and extensive monitoring is required.

Shekha (2016) conducted drinking water quality test of Greater Zab River located in Iraq. The sample analyzed for several physical parameters, minerals, and heavy metals indicated that the water of the Zab River is suitable for drinking purposes. Some of the works which are carried out throughout the globe on the quality of river water are presented in Tables 3 and 4.

\section{Water quality at high-altitude region}

\section{High-altitude region in different countries}

The high-altitude region sometime defined as the altitudinal region, which starts from 2400 meters above mean sea level (MSL). Some of the important high-altitude regions worldwide inhabited are listed in Table 5 and presented in Fig. 1. The high-altitude region has covered one-fifth of the total earth surface area. Various ecosystems characterize these high-altitude regions. Approximately thirteen hundred million people reside in this region, and this number fluctuates due to the dynamic population in terms of tourist (Zafren and Honigman 1997). The most crowded high-altitude region of India is Leh, Ladakh, whose data are presented in Fig. 2. Since 1996, at Ladakh, a high-altitude region of India, in terms of 


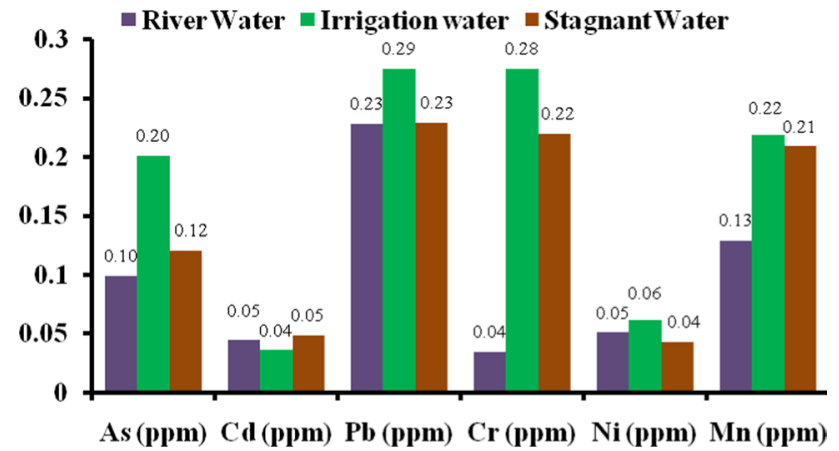

Fig. 6 Level of different metals in different sources of water at highaltitude region of India

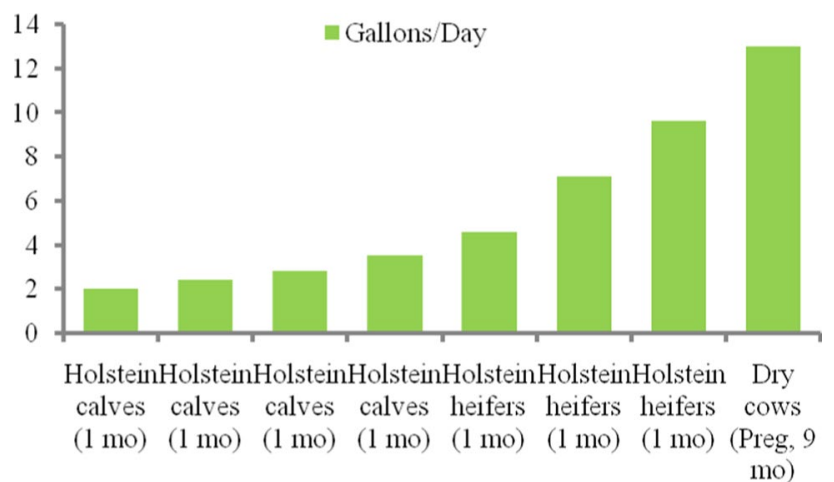

Fig. 7 Normal water intake of dairy cattle. Adopted from Adams and Sharpe (1914)

the dynamic flow of tourists, has increased to a hundred times (Fig. 3).

\section{Physicochemical, microbial, and heavy metal contamination at high altitude}

An evaluator study on water quality was conducted in Nepal located at the elevation of 4530 to $5480 \mathrm{~m}$ MSL. The study concluded that most of the lakes have poor water quality that might be due to the increase in atmospheric pollutant loads and geo-lithological changes (Gabriele et al. 2002). In Nepal, it found that at the elevation of 1900-5300 m MSL, water quality is going to deteriorate due to the increasing level of tourists and tracking in this area (Narayan et al. 2013). Earlier findings also indicated that Himalayan rivers like Alaknanda, Bhagirathi, Ganga, and Mandakini ware polluted due to the presence of $E$. coli (Kumar et al. 2010).

The water of Anchar Lake of Kashmir Valley was evaluated for different physicochemical parameters. It was found that most of the parameters showed a positive correlation except between dissolved oxygen and biological oxygen demand, and $\mathrm{pH}$ and dissolved carbon dioxide (Salim et al. 2013). Sukhnag stream is a significant inflow stream of Lake Wular. Data analyzed by multivariate statistical analysis indicated that total phosphorus, calcium, sodium, total solids, and total dissolved solids were the most effective factors for changing the pattern of water quality. The overall study showed that water quality is going to altered (Salem et al. 2014).

Different sources of water in Leh, Ladakh, a cold desert high-altitude region of India, were analyzed. Results showed that the level of $\mathrm{Mn}, \mathrm{Zn}$ and $\mathrm{Cr}$ was below the prescribed limit of $\mathrm{WHO}$, but $\mathrm{As}, \mathrm{Pb}, \mathrm{Ni}$, and $\mathrm{Cd}$ were higher than the WHO limits. The levels of different physicochemical and mineral parameters in various sources of water are presented in Figs. 4, 5 and 6. Long-term consumption of water may pave the health hazards to the local animals as well as to human (Charan 2013).
Fig. 8 Variation of relative humidity (RH), maximum temperature $\left(T_{\max }\right)$, and minimum temperature $\left(T_{\min }\right)$ of six consecutive years (2010-2015) at experimental location of Leh, Ladakh, Kashmir (Bharti et al. 2017a, b)

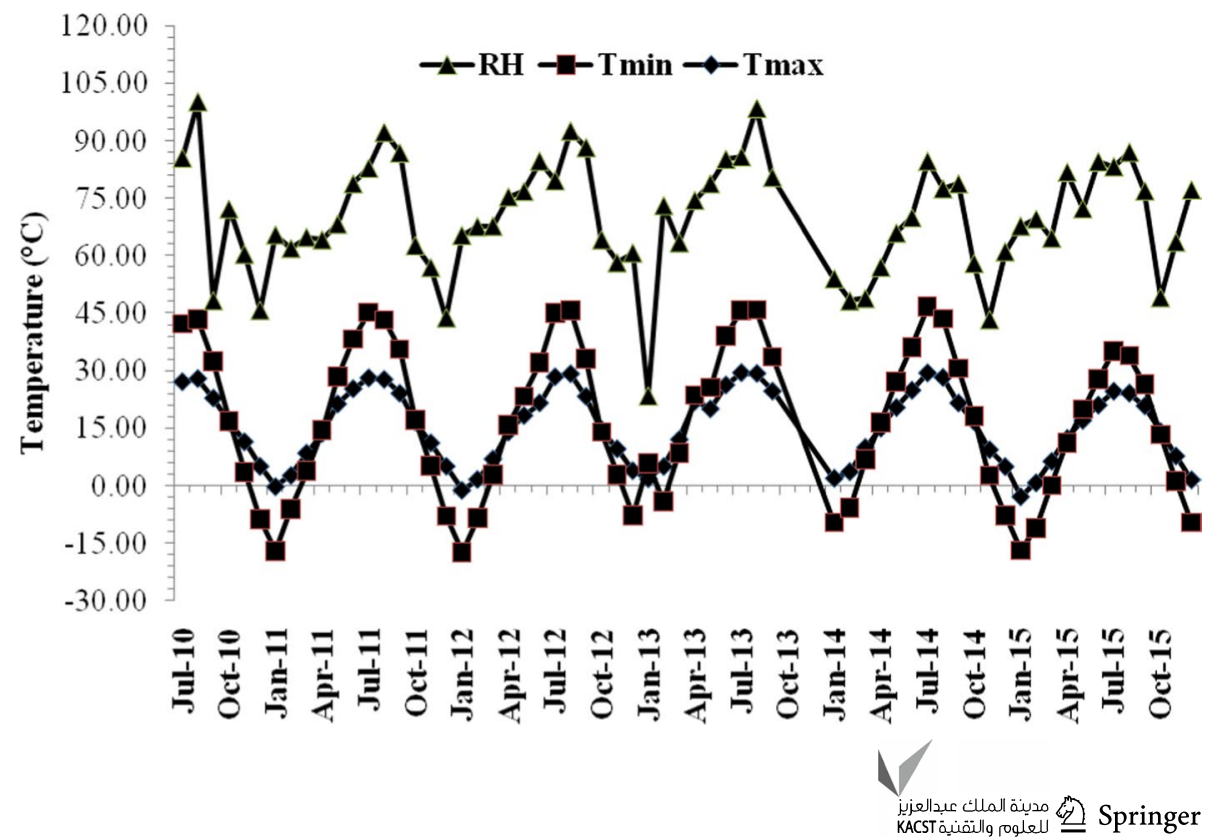


Table 6 Primary requirements of essential minerals in ruminants and non-ruminants (adopted from Underwood and Suttle 2001)

\begin{tabular}{|c|c|c|c|c|c|c|c|c|}
\hline Minerals & Sheep & References & Cattle & References & Pigs & References & Poultry & References \\
\hline Calcium & $4 \mathrm{~g} \mathrm{~kg}^{-1} \mathrm{DM}$ & AFRC (1991) & $\begin{array}{l}4.5 \mathrm{~g} \mathrm{~kg}^{-1} \\
\mathrm{DM}\end{array}$ & AFRC (1991) & $7.6 \mathrm{~g} \mathrm{~kg}^{-1} \mathrm{DM}$ & ARC (1981) & $8.5 \mathrm{~g} \mathrm{~kg}^{-1} \mathrm{DM}$ & NRC (1994) \\
\hline Phosphorus & $\begin{array}{l}1.7-3.8 \mathrm{~g} \mathrm{~kg}^{-1} \\
\mathrm{DM}\end{array}$ & NRC(1985) & $\begin{array}{l}2.2- \\
4.3 \mathrm{~g} \mathrm{~kg}^{-1} \\
\mathrm{DM}\end{array}$ & NRC (1975) & $\begin{array}{l}5.9-8.8 \mathrm{~g} \mathrm{~kg}^{-1} \\
\text { DM }\end{array}$ & ARC (1981) & $4.5 \mathrm{~g} \mathrm{~kg}^{-1} \mathrm{DM}$ & NRC (1994) \\
\hline Magnesium & $\begin{array}{l}0.7-1.8 \mathrm{~g} \mathrm{~kg}^{-1} \\
\text { DM }\end{array}$ & ARC (1980) & $\begin{array}{l}0.7- \\
1.8 \mathrm{~g} \mathrm{~kg}^{-1} \\
\mathrm{DM}\end{array}$ & ARC (1980) & $\begin{array}{l}400 \mathrm{mg} \mathrm{kg}^{-1} \\
\text { DM }\end{array}$ & NRC (1988) & $0.5 \mathrm{~g} \mathrm{~kg}^{-1} \mathrm{DM}$ & NRC (1994) \\
\hline Sodium & $\begin{array}{l}0.8-2.7 \mathrm{~g} \mathrm{~kg}^{-1} \\
\mathrm{DM}\end{array}$ & ARC (1980) & $\begin{array}{l}1.8 \mathrm{~g} \mathrm{~kg}^{-1} \\
\mathrm{DM}\end{array}$ & NRC (1989) & $\begin{array}{l}0.8-1.1 \mathrm{~g} \mathrm{~kg}^{-1} \\
\mathrm{DM}\end{array}$ & $\begin{array}{l}\text { Meyer et al. } \\
(1950)\end{array}$ & $\begin{array}{l}0.5-0.6 \mathrm{~g} \mathrm{~kg}^{-1} \\
\mathrm{DM}\end{array}$ & $\begin{array}{c}\text { Shaw and } \\
\text { Philips } \\
\text { (1953) }\end{array}$ \\
\hline Potassium & $3-5 \mathrm{~g} \mathrm{~kg}^{-1} \mathrm{DM}$ & ARC (1980) & $\begin{array}{l}6-8 \mathrm{~g} \mathrm{~kg}^{-1} \\
\mathrm{DM}\end{array}$ & $\begin{array}{l}\text { Thompson } \\
(1972) \text {, } \\
\text { NRC (1994) }\end{array}$ & $\begin{array}{l}2.6-3.3 \mathrm{~g} \mathrm{~kg}^{-1} \\
\text { DM }\end{array}$ & $\begin{array}{l}\text { Combs } \\
(1981) \text {, } \\
\text { Meyer et al. } \\
(1950)\end{array}$ & $4-6 \mathrm{~g} \mathrm{~kg}^{-1} \mathrm{DM}$ & $\begin{array}{c}\text { Thompson } \\
\text { (1972) }\end{array}$ \\
\hline Sulfur & $\begin{array}{l}1.1-1.6 \mathrm{~g} \mathrm{~kg}^{-1} \\
\mathrm{DM}\end{array}$ & ARC (1980) & $\begin{array}{l}1.1- \\
1.6 \mathrm{~g} \mathrm{~kg}^{-1} \\
\mathrm{DM}\end{array}$ & ARC (1980) & - & - & - & - \\
\hline Cobalt & $\begin{array}{l}0.07 \mathrm{mg} \mathrm{kg}^{-1} \\
\mathrm{DM}\end{array}$ & ARC (1980) & $\begin{array}{l}0.07 \mathrm{mg} \mathrm{kg}^{-1} \\
\mathrm{DM}\end{array}$ & ARC (1980) & $\begin{array}{l}10-18 \mu \mathrm{g} \mathrm{kg}^{-1} \\
\text { DM }\end{array}$ & ARC (1981) & $\begin{array}{l}\text { 3-10 } \mu \mathrm{g} \mathrm{kg}^{-1} \\
\mathrm{DM}\end{array}$ & NRC (1994) \\
\hline Copper & $\begin{array}{l}0.13- \\
0.18 \mathrm{mg} \mathrm{kg}^{-1} \\
\text { DM }\end{array}$ & ARC (1980) & $\begin{array}{l}\text { 4-6 mg kg } \\
\text { DM }\end{array}$ & ARC (1980) & $4 \mathrm{mg} \mathrm{kg}^{-1} \mathrm{DM}$ & ARC (1981) & $4 \mathrm{mg} \mathrm{kg}^{-1} \mathrm{DM}$ & NRC (1994) \\
\hline Iodine & $\begin{array}{c}50-100 \mu \mathrm{g} \\
\text { Day }^{-1}\end{array}$ & $\begin{array}{l}\text { Mitchell and } \\
\text { McClure } \\
(1937)\end{array}$ & $\begin{array}{c}400-800 \mu \mathrm{g} \\
\mathrm{Day}^{-1}\end{array}$ & $\begin{array}{l}\text { Mitchell and } \\
\text { McClure } \\
(1937)\end{array}$ & $\begin{array}{c}80-160 \mu \mathrm{g} \\
\text { Day }^{-1}\end{array}$ & $\begin{array}{l}\text { Mitchell and } \\
\text { McClure } \\
\text { (1937) }\end{array}$ & $\begin{array}{l}0.2- \\
1.0 \mathrm{mg} \mathrm{kg}^{-1} \\
\text { DM }\end{array}$ & $\begin{array}{l}\text { Wilgus et al. } \\
\text { (1953) }\end{array}$ \\
\hline Iron & $\begin{array}{l}25-40 \mathrm{mg} \mathrm{kg}^{-1} \\
\text { DM }\end{array}$ & $\begin{array}{l}\text { Lawlor et al. } \\
\text { (1965) }\end{array}$ & $\begin{array}{l}30- \\
60 \mathrm{mg} \mathrm{kg}^{-1} \\
\text { DM }\end{array}$ & $\begin{array}{l}\text { Matrone et al. } \\
\text { (1957) }\end{array}$ & $\begin{array}{l}40- \\
100 \mathrm{mg} \mathrm{kg}^{-1} \\
\text { DM }\end{array}$ & NRC (1988) & $\begin{array}{l}80 \mathrm{mg} \mathrm{kg}^{-1} \\
\mathrm{DM}\end{array}$ & NRC (1994) \\
\hline Manganese & $\begin{array}{l}13 \mathrm{mg} \mathrm{kg}^{-1} \\
\mathrm{DM}\end{array}$ & $\begin{array}{l}\text { Masters et al. } \\
\text { (1988) }\end{array}$ & $\begin{array}{l}20- \\
25 \mathrm{mg} \mathrm{kg}^{-1} \\
\text { DM }\end{array}$ & ARC (1980) & $4 \mathrm{mg} \mathrm{kg}^{-1} \mathrm{DM}$ & NRC (1988) & $\begin{array}{l}60 \mathrm{mg} \mathrm{kg}^{-1} \\
\mathrm{DM}\end{array}$ & NRC (1994) \\
\hline Selenium & $\begin{array}{l}0.03 \mathrm{mg} \mathrm{kg}^{-1} \\
\mathrm{DM}\end{array}$ & $\begin{array}{l}\text { Grace et al. } \\
\text { (1994) }\end{array}$ & $\begin{array}{l}0.07 \mathrm{mg} \mathrm{kg}^{-1} \\
\mathrm{DM}\end{array}$ & $\begin{array}{l}\text { Grace et al. } \\
\text { (1994) }\end{array}$ & $\begin{array}{l}0.16 \mathrm{mg} \mathrm{kg}^{-1} \\
\text { DM }\end{array}$ & ARC (1981) & $\begin{array}{l}0.20- \\
0.28 \mathrm{mg} \mathrm{kg}^{-1} \\
\text { DM }\end{array}$ & NRC (1994) \\
\hline Zinc & $\begin{array}{l}20-51 \mathrm{mg} \mathrm{kg}^{-1} \\
\text { DM }\end{array}$ & ARC (1980) & $\begin{array}{l}12- \\
34 \mathrm{mg} \mathrm{kg}^{-1} \\
\text { DM }\end{array}$ & ARC (1980) & $\begin{array}{l}50 \mathrm{mg} \mathrm{kg}^{-1} \\
\mathrm{DM}\end{array}$ & NRC (1988) & $\begin{array}{l}50 \mathrm{mg} \mathrm{kg}^{-1} \\
\mathrm{DM}\end{array}$ & NRC (1977) \\
\hline
\end{tabular}

According to the investigation carried out by Bharti et al. (2017a) on water quality of different sources in Leh District, a high-altitude region situated above the $3500 \mathrm{~m}$ MSL, India, it was found that alkalinity and hardness were higher than the prescribed limit of WHO. The study concluded that more or less water quality is safe for drinking purposes in this region.

Another extensive study was carried out in the same highaltitude region on groundwater quality and evaluated total twenty-five parameters in seventy number of groundwater samples collected from different sites of Leh in both summer and winter seasons (Giri et al. 2017). Results showed that water quality levels go down due to the dissolution process of salts, leaching process, and increased level of population in terms of tourists (Fig. 3).

\section{Persistent organic pollutants (POPs) at high altitude}

Due to globalization, the untouched area of the earth, like many high-altitude regions, is getting crowded, and several studies indicate that the level of persistent organic pollutants (POPs) is getting higher. Dichlorodiphenyltrichloroethane (DDT), polychlorinated biphenyls (PCBs), and polybrominated diphenyl ethers (PBDEs) are the essential POPs. All these pollutants are depositing at high-altitude regions by transport and day-by-day increasing trend of tourists at these places. POPs are getting lodged in the snow layer, and 
Table 7 Some important metalloenzymes in livestock (adopted from Underwood and Suttle 2001)

\begin{tabular}{lll}
\hline Metal & Enzyme & Function \\
\hline Iron & Succinate dehydrogenase & Aerobic oxidation of carbohydrates \\
Copper & Cytochromes a, b and c & Electron transfer \\
& Catalase & Protection against $\mathrm{H}_{2} \mathrm{O}_{2}$ \\
& Cytochrome oxidase & Terminal oxidase \\
& Lysyl oxidase & Lysine oxidation \\
& Ceruloplasmin & Iron utilization: copper transport \\
Zinc & Superoxide dismutase & Dismutation of superoxide radical $\mathrm{O}_{2}^{-}$ \\
& Carbonic anhydrase & CO \\
& Alcohol dehydrogenase & Alcohol metabolism \\
& Carboxypeptidase A & Protein digestion \\
& Alkaline phosphatase & Hydrolysis of phosphate esters \\
& Nuclear poly(A) polymerase & Cell replication \\
& Collagenase & Wound healing \\
Manganese & Pyruvate carboxylase & Pyruvate metabolism \\
& Super oxide dismutase & Antioxidant by removing $\mathrm{O}_{2}^{-}$ \\
& Glycosyl aminotransferases & Proteoglycan synthesis \\
Molybdenum & Xanthine dehydrogenase & Purine metabolism \\
& Sulfite oxidase & Sulfite oxidation \\
& Aldehyde oxidase & Purine metabolism \\
& Glutathione peroxidase (four) & Removal of $\mathrm{H}_{2} \mathrm{O}_{2}$ and hydroperoxidase \\
& Type II and III deiodinase & Conversion of thyroxine to active form \\
\hline & & \\
& &
\end{tabular}

Table 8 Pathophysiology of mineral-responsive diseases in dairy cattle (adopted from Underwood and Suttle 2001)

\begin{tabular}{lllll}
\hline Minerals & Depletion & Deficiency & Dysfunction & Disease \\
\hline Calcium & Young: bone $\downarrow$ & Serum & Chondrodystrophy & Rickets \\
& Old: bone $\downarrow$ & Serum & Irritability $\downarrow$ & Recumbency \\
Magnesium & Young: bone $\downarrow$ & Serum & Irritability $\uparrow$ & Convulsion \\
& Old: bone & Serum & Irritability $\uparrow$ & Convulsion \\
Copper & Liver $\downarrow$ & Serum & Disulfide bonds $\downarrow$ & Wool crimp $\downarrow$ \\
Cobalt & Liver $\mathrm{B}_{12} \downarrow$ & Serum & MMA $\uparrow$ & Inappetence \\
& Serum $\mathrm{B}_{12} \downarrow$ & $<350$ pmol $1^{-1}$ & & \\
Iodine & $\mathrm{T}_{4} \downarrow$ & $\mathrm{T}_{3} \downarrow$ & BMR $\downarrow$ & Goiter \\
& Thyroid colloid $\downarrow$ & & Thyroid hypertrophy & \\
& Thyroid I $\downarrow$ & & & Serum creatine kinase $\uparrow$ \\
Selenium & GSH-Px in erythrocyte $\downarrow$ & Serum Se $\downarrow$ & Myopathy \\
& & & & gangrene of \\
& & & & ear/tail \\
\hline
\end{tabular}

in summer, they leached to the underground water (Olatunji 2019). One study on the presence of POPs at highaltitude region of Italy conducted. The results of these study revealed that the study area is slightly contaminated with POPs (Giulia et al. 2017). Environmentally pertinent POPs affect the cellular level to exert the neurotoxic effects in the animals (Kodavanti 2006).

\section{Impact of water quality on dairy cattle}

Dairy cattle reproduction and production depend upon the water and feed quality, and water plays a vital role in providing some essential nutrients. Nowadays, dairy production is 
Table 9 Safe concentrations of some potentially toxic nutrients and contaminants in water for cattle

\begin{tabular}{llll}
\hline Chemical compounds & $\begin{array}{l}\text { Abbreviation of } \\
\text { compounds }\end{array}$ & Threshold level ${ }^{\mathrm{a}}(\mathrm{mg} / \mathrm{l})$ & $\begin{array}{l}\text { Highest desir- } \\
\text { able limit } \\
(\mathrm{mg} / \mathrm{l})\end{array}$ \\
\hline Aluminum & $\mathrm{Al}$ & & 0.5 \\
Arsenic & $\mathrm{As}$ & 5.0 & 0.05 \\
Boron & $\mathrm{B}$ & 0.2 & 5.0 \\
Cadmium & $\mathrm{Cd}$ & 5.0 & 0.005 \\
Chromium & $\mathrm{Cr}$ & 0.05 & 0.1 \\
Cobalt & $\mathrm{Co}$ & 1.0 & 1.0 \\
Copper & $\mathrm{Cu}$ & 1.0 & 1.0 \\
Fluoride & $\mathrm{F}$ & 0.5 & 2.0 \\
Lead & $\mathrm{Pb}$ & 2.0 & 0.015 \\
Manganese & $\mathrm{Mn}$ & 0.1 & 0.05 \\
Mercury & $\mathrm{Hg}$ & Not available & 0.01 \\
Nickel & $\mathrm{Ni}$ & 0.01 & 0.25 \\
Nitrogen dioxide & $\mathrm{NO}-\mathrm{N}$ & 1.0 & - \\
Selenium & $\mathrm{Se}$ & 10.0 & 0.05 \\
Vanadium & $\mathrm{V}$ & 0.05 & 0.1 \\
Zinc & $\mathrm{Zn}$ & 0.1 & 5.0 \\
Salinity (total soluble salts) & $\mathrm{Sal}$ & 25.0 & - \\
Toxic algae & - & 3000.0 & - \\
\hline & & No heavy growth & \\
\hline & & & \\
\hline
\end{tabular}

${ }^{\mathrm{a}}$ Ontario Ministry of the Environment 1984

${ }^{b}$ NRC (1975, 1980), EPA (2009)

${ }^{\mathrm{c}}$ No value available going to decrease due to the lack of attention for the proper nutrition and health management of dairy cattle by farmers and nutritionists. It is found that, from any other landmass animal, dairy cows have the highest water requirements for proper performance, as $80 \%$ of water is required for milk synthesis (Woodford et al. 1984). Daily water intake by dairy cattle is presented in Fig. 7. In the animal body, water helps in proper digestion, energy metabolism, and electrolyte balance. It also helps in nutrient and metabolites transport to and from the tissue by the circulatory system. It plays a vital role in excretion, proper ion, and heat balance. Water maintains the fluidity and cushioning environment for the developing fetus in the animal body (Murphy 1992). Therefore, water is considered an essential nutrient for dairy cattle. However, the role of water in cattle body depends upon the source and quality of water. Most of the farmers and the dairy farms have no accessibility for water quality testing facility. The micro-eco-geology of water sources is very complicated as the mechanism of this complex in the animal body is less understood (Van Eenige et al. 2013). Requirements of water minerals nutrients in ruminants and nonruminants are listed in Table 6. Among all these minerals nutrients, most of them act as the cofactor in most essential enzymes in the cattle body. Minerals that are necessary for the enzymatic activity are listed in Table 7 . In the deficiency of these minerals, several diseases occurred, which are listed in Table 8.

Poor quality of water affects herd health through adversely changing feed intake, body nutrients balance, milk production, and reproduction. Toxic pollutants present in the water may bioaccumulate in the animal body which in turn may affect the whole human population after contaminated milk consumption. Therefore, regular evaluation of water quality may reduce the health hazzard in a dairy herd (Wegener 2012). Hence, the priority must be to provide to access of potable water to every individual and whole community. Microbe-contaminated water adversely affects human and animal health due to outbreaks of waterborne diseases and may cause an epidemic situation (Watson et al. 2007). Chemical aspects of water quality have less acute effects on human health, whereas long-term exposure causes chronic effects and, within time, may be curable. Possible encounters by chemical aspects of water quality may be affected by human health, where levels of certain chemicals are at excessive levels due to the high natural or anthropogenic activity (Hunter et al. 2010; Jaishankar et al. 2014). Eight liters of unpolluted water may turn too polluted by only one liter of contaminated water. One survey by UNESCO in India found that 115 million homes are without toilets and the domestic sewage contributed about $75 \%$ (UNESCO 2003). However, current government schemes and clean village mission 


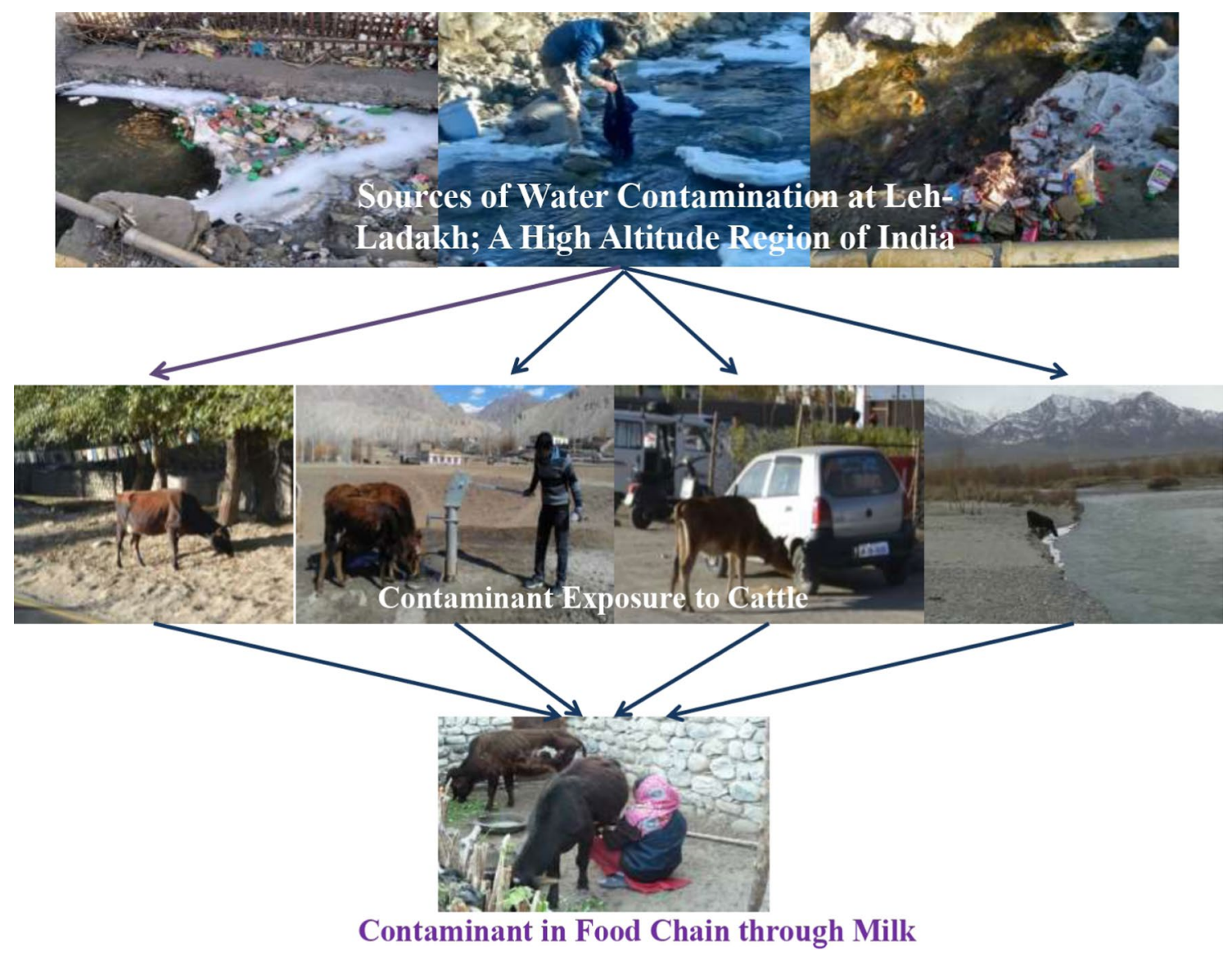

Fig. 9 Schematic presentation of different water sources (hand pump water, river water) contamination and bioaccumulation cycle in dairy cattle herd at Leh, Ladakh, India

increased the water sanitation through minimization of open defecation and increase in toilets number.

On the other hand, farmers do not pay much attention to water quality for crop irrigation and animal drinking, which may affect the health status of animals through affecting metabolic activity. Water contaminated with higher levels of sulfate significantly decreased the water intake of cattle. High levels of sulfate in dairy cattle affect their normal metabolic pathways (Grout et al. 2006). It has been found that TDS in drinking water controls the water intake behavior of domestic animals. If the TDS level is low, then it was proved that the water intake by animals decreases. Consequently, it also established that the decrease in water and feed intake of animals will lead to poor growth and production of animals (Bharti et al. 2017b; Kalia et al. 2017; Giri et al. 2017). The normal level of water containing minerals and metals in cattle body is represented in Table 9 .

With the changing scenario of climate due to global warming, precipitation patterns also are changing. Weather data at Leh, Ladakh, India, are presented in Fig. 8; it is an indicator of global warming and climate changes. So for cultivation, farmers are abruptly using the groundwater instead of surface water. Over abstraction of groundwater has to change the hydrogeochemical and biological processes in the rock-soil system. Therefore, it is a great concern to check the groundwater quality for the physical and chemical properties (Hasanuzzaman et al. 2017). In Leh, drinking water facilities are not acceptable. Nearly half of the population in this region uses drinking water from public sources, and approximately eight percent of the households depend upon private sources. Natural water sources like running river, snowmelt water, and deep bore well groundwater also play a significant role as a source of drinking water in this region. The dependency of the local populace on the private source of water may increase by the unique vision of the government in this region. A few decades before, people of Leh were using mostly river water for drinking and other purposes. The surface water was as so clean and sweet as that of the adjoining springs. However, due to the increase in population and human settlements nearby water sources, people let the sewage drain into the river and thus polluted the available surface water. The most probable contaminate way in different water sources and dairy cattle herd at Leh, a high-altitude region of India, is presented in Fig. 9. Now,

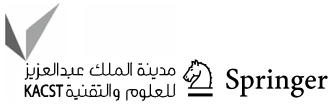


the people are compelled to use only the groundwater for drinking purposes in many places (Ground Water Information Brochure of Leh District 2011; Giri et al. 2017).

\section{Conclusion}

Most of the research work on groundwater and surface water showed that physicochemical, microbial, minerals, and heavy metals levels were higher than the prescribed limits as per the WHO, APHA, EPA, OSHA, ISI, ICMR guidelines throughout the world. Our study revealed that water quality is also going to deteriorate at high-altitude region of Leh, Ladakh, and other region worldwide due to global warming and increased anthropogenic activities. The main causal factors of water quality at high altitude bear upon the cattle health including excess mineral level, high bacterial load, presence of persistent organic pollutants, and high level of heavy metals. The poor availability and quality of drinking water would affect the dairy cattle health and production at both high-altitude and low-altitude regions. Henceforth, myth that water is neat and clean in the mountain region is now breaking. From this review, it can be concluded that due to global warming and an increase in tourists at high-altitude regions, water quality is getting deteriorate tremendously, which may affect the reproduction and milk production of dairy cattle. Therefore, it is the earliest time to prevent such alteration of water quality by inventing some ameliorative measurements so that cattle herd health and the productivity may be protected for quality dairy produce production. This will help in better health of dairy produce consumers and minimizing bioaccumulation of some toxic molecules in higher food chain.

Open Access This article is licensed under a Creative Commons Attribution 4.0 International License, which permits use, sharing, adaptation, distribution and reproduction in any medium or format, as long as you give appropriate credit to the original author(s) and the source, provide a link to the Creative Commons licence, and indicate if changes were made. The images or other third party material in this article are included in the article's Creative Commons licence, unless indicated otherwise in a credit line to the material. If material is not included in the article's Creative Commons licence and your intended use is not permitted by statutory regulation or exceeds the permitted use, you will need to obtain permission directly from the copyright holder. To view a copy of this licence, visit http://creativecommons.org/licenses/by/4.0/.

\section{References}

Adams RS, Sharpe WE (1914) Water intake and quality for dairy cattle. Department of Dairy and Animal Science, The Pennsylvania State University, University Park, pp 1-7

Affum AO, Osae SD, Nyarko BJB, Afful S, Fianko JR, Akiti TT, Adomako D, Acquaah SO, Dorleku ME, Barnes AF, Affum EA (2015) Total coliforms, arsenic and cadmium exposure through drinking water in the Western Region of Ghana: application of multivariate statistical technique to groundwater quality. Environ Monit Assess 187:1-23

AFRC (1991) Technical committee ON responses to nutrients report no. 6. A reappraisal of the calcium and phosphorus requirements of sheep and cattle. Nutr Abstr Rev 61:573-612

Alves NC, Augusto CO, Goulart FC (2002) Microbiological analysis of mineral water and drinking water of reservoir supplies, Brazil. Revista de Saúde Pública 36:749-751

Ambedkar G, Muniyan M (2012) Analysis of heavy metals in water, sediments and selected freshwater fish collected from Gadilam River, Tamilnadu, India. Int J Toxicol Appl Pharmacol 2:25-30

ARC (1980) The Nutrient Requirements of Ruminant Livestock. Commonwealth Agricultural Bureaux, Farnham Royal, pp 201-211

ARC (1981) The nutrient requirements of pigs. Commonwealth Agricultural Bureaux, Farnham Royal, pp 215-248

Aris AZ, Abdullah MH, Woong KK, Praveena SM (2009) Hydrochemical changes in small Tropical Island's aquifer: manukan Island, Sabah, Malaysia. Environ Geol 56:1721-1732

Barik D, Thorat A (2015) Issues of unequal access to public health in India. Front Public Health 3:245

Bariki SK, Byragi RT, Saramanda G (2015) Assessment of physicochemical quality of drinking water in Araku Valley Mandal of Visakhapatnam District, Andhra Pradesh, India. Int J Sci Technol 3:177-183

Barnes DKA, Galgani F, Thompson RC, Barlaz M (2009) Accumulation and fragmentation of plastic debris in global environments. Philos Trans R Soc B Biol Sci 364:1985-1998

Bharti VK, Giri A, Kumar K (2017a) Evaluation of physico-chemical parameters and minerals status of different water sources at high altitude. Peertechz J Environ Sci Toxicol 2:10-18

Bharti VK, Giri A, Vivek P, Kalia S (2017b) Health and productivity of dairy cattle in high altitude cold desert environment of LehLadakh: a review. Indian J Anim Sci 87:3-10

Bhuyan S, Bakar MA (2017) Seasonal variation of heavy metals in water and sediments in the Halda River, Chittagong, Bangladesh. Environ Sci Pollut Res 2017:1-14

Bourasi SK, Singh SD, Patil P, Parihar SS, Taunk A (2016) Seasonal variation of physico-chemical parameter and diversity of phytoplankton in river Narmada at Harda (M.P.). CIBTech J Microbiol 5:25-30

Charan G (2013) Studies on certain essential minerals status and heavy metals presents in soil, plant, water and animal at high altitude cold arid environment, Ph.D. Thesis, JAYPEE University of Information Technology, Waknaghat, Solan, India

Chiwome B, Kandiwa E, Mushonga B, Sajeni S, Habarugira G (2017) A study of the incidence of milk fever in Jersey and Holstein cows at a dairy farm in Beatrice, Zimbabwe. J S Afr Vet Assoc 88:e1-e6

Combs GF Jr (1981) Influence of dietary vitamin E and selenium on the oxidant defence system of the chick. Poult Sci 60:2005-2098

Cowan V, Blakley B (2016) Acute lead poisoning in western Canadian cattle-a 16-year retrospective study of diagnostic case records. Can Vet J 57:421-426

Daud MK, Nafees M, Ali S, Rizwan M, Bajwa RA, Shakoor MB, Zhu SJ (2017) Drinking water quality status and contamination in Pakistan. Biomed Res Int 2017:7908183

Debels P, Ricardo F, Roberto U, Ricardo B, Xavier N (2005) Evaluation of water quality in the Chillan river (central Chile) using physicochemical parameters and a modified water quality index. Environ Monit Assess 110:301-322

EPA (U.S. Environmental Protection Agency) (2009) National primary drinking water regulations. EPA 816-F-09-004. http:// www.epa.gov/ogwdw/consumer/pdf/mcl.pdf. Accessed 26 Dec 2011 
Eze SO, Chigbu CG (2015) Physical, Chemical and Microbiological Parameters of Iyi Okai Stream in Abiriba, Ohafia Local Government Area, Abia State, Nigeria. European Journal of Pure and Applied Chemistry 2:8-22

Gabriele AT, Gianni T, Rosario M (2002) Water chemistry of high altitude lakes in the Khumbu and Imja Kola valleys (Nepalese Himalayas). Limnology of high altitude lakes in the Mt Everest Region (Nepal). Mem Ist Ital Idrobiol 57:51-76

Giri A (2018) Studies on trace minerals and heavy metals status in different sources of water and their bioavailability in milking cattle at high altitude. Ph.D. Thesis (submitted), Bharathiar University, Coimbatore, Tamilnadu, India

Giri A, Bharti VK, Kalia S, Kumar K, Raj T, Kumar B (2017) Utility of multivariate statistical analysis to identify factors contributing ground water quality in high altitude region of Leh-Ladakh, India. Asian J Water Environ Pollut 14:61-75

Giulia P, Franco S, Claudio R, Stefano N, Licia G (2017) Persistent organic pollutants in sediments of high-altitude Alpine ponds within Stelvio National Park, Italian Alps. Inland Waters 7:34-44

Grace ND (1994) Managing tree element deficiencies. New Zealand Pastoral Agriculture Research Institute, Palmerston North, pp 9-24

Ground Water Information Brochure of Leh District, Jammu and Kashmir State. (2011). http://www.cgwb.gov.in/District_Profile/JandK /Leh.pdf

Grout AS, Veira DM, Weary DM, von Keyserlingk MAG, Fraser D (2006) Differential effects of sodium and magnesium sulfate on water consumption by beef cattle. J Anim Sci 84:1252-1258

Hasanuzzaman M, Xianfang S, Dongmei H, Yinghua Z, Shakir H (2017) Prediction of groundwater dynamics for sustainable water resource management in Bogra District, Northwest Bangladesh. Water 9:238

Huang G, Sun J, Zhang Y, Chen Z, Liu F (2013) Impact of anthropogenic and natural processes on the evolution of groundwater chemistry in a rapidly urbanized coastal area, South China. Sci Total Environ 463-464:209-221

John E (2009) Physico-chemical studies of river Pumba and distribution of prawn, Macrobrachium rosenbergii. J Environ Biol 30:709-712

Kalia S, Bharti VK, Gogoi D, Giri A, Kumar B (2017) Studies on the growth performance of different broiler strains at high altitude and evaluation of probiotic effect on their survivability. Sci Rept 7:46074

Khalik WMA, Abdullah WM, Amerudin NA, Padli N (2013) Physicochemical analysis on water quality status of Bertam River in Cameron Highlands, Malaysia. J Mater Environ Sci 4:488-495

Kodavanti PR (2006) Neurotoxicity of persistent organic pollutants: possible mode(s) of action and further considerations. Dose Response 3:273-305

Kumar A, Bisht BS, Joshi VD, Singh AK, Talwar A (2010) Physical, chemical and bacteriological study of water from rivers of Uttarakhand. J Hum Ecol 32:169-173

Kumar P, Singh AN, Shrivastava R, Mohan D (2015) Assessment of seasonal variation in water quality dynamics in river varuna-a major tributary of River Ganga. Int J Adv Res 3:1176-1193

Kumar R, Chauhan A, Rawat L (2017) Physico-chemical analysis of surface and ground water in selected sites of Dehradun, Uttarakhand, India. J Environ Anal Toxicol 6:420

Lawlor MJ, Smith WH, Beeson WM (1965) Iron requirement of the growing lamb. J Anim Sci 24:742-747

Liu Y, Kujawinski EB (2015) Chemical composition and potential environmental impacts of water-soluble polar crude oil components inferred from ESI FT-ICR MS. PLoS ONE 10:e0136376

Mark WR, Ximing C, Sarah AC (2002) World water and food to 2025: dealing with security. International Food Policy Research Institute, Washington
Masters DG, Paynter DI, Briegel J, Baker SK, Purser DB (1988) Influence of manganese intake on body, wool and testicular growth of young rams and the concentration of manganese and the activity of manganese enzymes in tissues. Aust J Agric Res 39:517-524

Matrone G, Conley C, Wise GH, Waugh RK (1957) A study of iron and copper requirements of dairy calves. J Dairy Sci 40:1437-1447

Meyer JH, Grummer RH, Phillips RH, Bohstedt G (1950) Sodium, chlorine, and potassium requirements of growing pigs. J Anim Sci 9:300-306

Mitchell HH, MacClure FJ (1937) Mineral nutrition of farm animals. Bulletin No. 99. National Research Council, NewYork

Mountains of the World. Sustainable development in mountain areas. The need for adequate policies and instruments. Prepared for the world summit on sustainable development 2002 in Johannesburg. Centre for Development and Environment (CDE), Institute of Geography, University of Berne, Switzerland. pp 1-60. https:// www.cbd.int/doc/case-studies/tttc/tttc-00170-en.pdf

Murphy MR (1992) Water metabolism of dairy cattle. J Dairy Sci 75:326-333

Narayan PG, Pramod KJ, Gianumberto C (2013) Physico-Chemical Parameters of High-Altitude Rivers in the Sagarmatha (Everest) National Park. Nepal. J Water Resource Prot 5:761-767

Narsimha A, Geetha S, Sudarshan V, Swathi P, Srinivasulu P (2012) Physico-chemical analysis of drinking water quality in Hanamkonda area, Warangal District, Andhra Pradesh, India. J Chem Pharmaceut Res 4:4255-4259

National Research Council (NRC) (1975) Nutrient requirements of beef cattle, 5th edn. National Academy of Sciences, Washington, DC

National Research Council (NRC) (1977) Nutrient Requirements of Poultry, 7th edn. National Academy of Sciences, Washington, DC

National Research Council (NRC) (1980) Mineral Tolerances of Domestic Animals. National Academy of Sciences, Washington, DC

National Research Council (NRC) (1985) Nutrient requirements of sheep, 6th edn. National Academy of Sciences, Washington, DC

National Research Council (NRC) (1988) Nutrient requirements of swine, 9th edn. National Academy of Sciences, Washington, DC

National Research Council (NRC) (1994) Nutrient requirements of poultry, 9th edn. National Academy of Sciences, Washington, DC

National Research Council (NRC). Food and Nutrition Board (1989) Recommended dietary allowances, 10th edn. National Academy Press, Washington, DC

Okegye JI, Gajere JN (2015) Assessment of heavy metal contamination in surface and ground water resources around Udege Mbeki Mining District, North-Central Nigeria. J Geol Geophys 4:203

Olatunji OS (2019) Evaluation of selected polychlorinated biphenyls (PCBs) congeners and dichlorodiphenyltrichloroethane (DDT) in fresh root and leafy vegetables using GC-MS. Sci Rep 9:538

Patra AK, Sengupta S, Datta T (2011) Physico-chemical properties and ichthyofauna diversity in Karala River, a tributary of Teesta River at Jalpaiguri district of West Bengal, India. Int J Appl Biol Pharmaceut Technol 2:47-58

Potasznik A, Szymczyk S (2015) Magnesium and calcium concentrations in the surface water and bottom deposits of a river-lake system. J Elementol 20:677-692

Priyanka M, Dey S (2018) Ruminal impaction due to plastic materials-an increasing threat to ruminants and its impact on human health in developing countries. Vet World 11:1307-1315

Rango T, Kravchenko J, Atlaw B, McCornick PG, Jeuland M, Merola B, Vengosh A (2012) Groundwater quality and its health impact: an assessment of dental fluorosis in rural inhabitants of the Main Ethiopian Rift. Environ Int 43:37-47

Rodríguez-Tapia L, Morales-Novelo JA (2017) Bacterial pollution in river waters and gastrointestinal diseases. Int J Environ Res Public Health 14:479

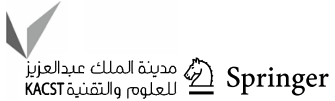


Sahoo M, Mahananda MR, Seth P (2016) Physico-chemical analysis of surface and groundwater around Talcher Coal Field, District Angul, Odisha, India. J Geosci Environ Prot 4:26-37

Salem WM, Sayed WF, Damarany KA (2014) Seasonal physicochemical and microbiological pollutants of potable groundwater in Qena governorate, Egypt: a case study. Afr J Environ Sci Technol 8:730-739

Salim AB, Gowhar M, Sayar V, Bhat R, Pandit AK (2013) Assessing the impact of anthropogenic activities on spatio-temporal variation of water quality in Anchar lake, Kashmir Himalayas. Int J Environ Sci 3:1625-1640

Sarma J, Mimi DS, Bormudoi A (2017) Analysis of water quality index parameters and its seasonal variations along the Kolong River, Assam, India. Int Res J Eng Technol 4:2589-2598

Sasikala S, Muthuraman G, Ravichandran K (2015) Water quality analysis of surface water sources near Tindivanam Taluk. Ind Chem 1:106

Shally SC, Keot A, Das H, Das M, Baishya C, Sarma A, Deka P (2016) Preliminary physicochemical and microbiological analysis of Bahini river water of Guwahati, Assam, India. Int J Curr Microbiol Appl Sci 5:684-692

Shaw RK, Philips PH (1953) The potassium and sodium requirements of certain mammals. Lancet 73:176

Shekha YA (2016) Evaluation of water quality for Greater Zab River by principal component analysis/factor analysis. Iraqi J Sci 57:2650-2663

Shittu OB, Olaitan JO, Amusa TS (2008) Physico-chemical and bacteriological analyses of water used for drinking and swimming purposes in Abeokuta, Nigeria. Afr J Biomed Res 11:285-290

Singh CK, Shashtri S, Mukherjee S (2011) Integrating multivariate statistical analysis with GIS for geochemical assessment of groundwater quality in Shiwaliks of Punjab, India. Environ Earth Sci 62:1387-1405

Solange L, Ernest AK, Blaise KY, François KN, Michel KA, Jean B (2013) Microbiological and physico-chemical quality of groundwater from artisanal sites of mining exploitation in the SouthWest of Côte d'Ivoire: case of the area of Hiré. Int J Sci Eng Res 4:567-574

Thompson DJ (1972) Potassium in animal nutrition. International Minerals and Chemical Corporation, Libertyville

Tikenbala DH, Ghosh CK, Datta BK, Dasgupta R, Mukhopadhayay S, Mandal TK (2010) Impact of arsenic exposure on bovine health and environmental pollution with special emphasis on ground water system in Manipur. Indian J Anim Sci 80:642-646

Ukponga EC, Peter BU (2012) Physico-chemical and bacteriological analyses of drinking water in Ibeno local government area of Akwa Ibom State. Niger J Technol 31:116-127
Underwood EJ, Suttle NF (2001) The mineral nutrition of livestock, 3rd edn. CABI Publishing, Wallingford

United Nations Educational, Scientific and Cultural Organizations (UNESCO) (2003) Water for people-water for life. The United Nations world water development report 1, Barcelona

Vaishnavi MVS, Gupta S (2015) Study of levels of heavy metals in the river waters of regions in and around Pune City, Maharashtra, India. Int J Ecol Ecosolut 2:36-40

Van Eenige MJ, Counotte GH, Noordhuizen JP (2013) Drinking water for dairy cattle: always a benefit or a microbiological risk? Tijdschr Diergeneeskd 138:86-97

Venkatesharaju K, Ravikumar P, Somashekar RK, Prakash KL (2010) Physico-chemical and Bacteriological Investigation on the river Cauvery of Kollegal Stretch in Karnataka. J Sci Eng Technol 6:50-59

Watson JT, Gayer M, Connolly MA (2007) Epidemics after natural disasters. Emerg Infect Dis 13:1-5

Wegener HC (2012) Antibiotic resistance-linking human and animal health. In: Institute of Medicine (US). Improving food safety through a one health approach: workshop summary. National Academies Press, Washington, p A15. https://www.ncbi.nlm.nih. gov/books/NBK114485/

WHO (2002) World health report: reducing risks—-promoting healthy life, Geneva

WHO (2013) Water sanitation and health: facts and figures on water quality and health. World Health Organization, Switzerland. http://www.who.int/water_sanitation_health/factsfigures/en/. Accessed 10 July 2013

Wilgus HS, Gassner FX, Patton AR, Harshfield GS (1953) The iodine requirements of chickens. Technical bulletin no. 49. Colorado Agricultural Experiment Station, Fort Collins

Woodford ST, Murphy MR, Davis CL (1984) Water dynamics of dairy cattle as affected by initiation of lactation and feed intake. J Dairy Sci 67:2336-2343

Zafren K, Honigman B (1997) High-altitude medicine. Emerg Med Clin North Am 15:191-222

Publisher's Note Springer Nature remains neutral with regard to jurisdictional claims in published maps and institutional affiliations. 